\title{
An Investigation of Learning Style Preferences on the Students' Academic Achievements of English
}

\author{
Norma Nawaf Yousef Al-Zayed ${ }^{1}$ \\ ${ }^{1}$ Department of English at Middle East University, Faculty of Arts and Sciences, Amman, Jordan \\ Correspondence: Norma Nawaf Yousef Al-Zayed, Department of English at Middle East University, Faculty of \\ Arts and Sciences, Amman, Jordan. E-mail: dr_normaalzayed@hotmail.com
}

Received: April 12, 2017 Accepted: May 28, 2017 Online Published: July 36, 2017

doi:10.5539/ijel.v7n5p176 URL: http://doi.org/10.5539/ijel.v7n5p176

\begin{abstract}
This study aims to investigate whether there are any statistically significant correlation between perceptual learning styles and achievement. Raising learners' awareness regarding their learning styles and preferences, which develops the better understanding of the learning achievement, and help instructors become more conscious of some factors affecting academic achievement. Additionally, the study assists instructors to identify their student's preferred learning styles that can affect their achievement. Furthermore, no study up to now has been conducted in Jordan which investigates the relationship between the learning styles on the achievement of EFL at the tertiary level. The data was collected through the learning style preferences questionnaire and it was analyzed using statistical techniques, Descriptive statistics showed that: 1). The most preferred learning styles followed the auditory style, group learning style, kinesthetic style and visual style. 2). The finding also revealed that there was no statistically significant correlation between learning style and achievement. Additionally, both showed similar references for kinesthetic and visual styles. Based on these findings, some recommendations have been made.
\end{abstract}

Keywords: visual, auditory, kinesthetic, EFL

\section{Introduction}

\subsection{Statement of the Problem}

Learning styles conducted by Jordanian students do not correlate to the foreign language achievement because teachers, parents and administrators fail to consider the different styles when assessing students. This leaves the students with one style that they are used to. What worsens the situation is that Jordanian learners are unaware of the idea that there are various learning styles; other learners adhere to while learning a target language. Therefore, the main purpose of the current study, firstly, was to identify the learning styles of the students and to identify the learning styles preferences of students on academic achievement in English.

\subsection{Significance of the Study}

Very few researchers have empirically examined the role of the learning styles in relation to foreign language proficiency compared to the huge amount of research that has been conducted to assist curriculum designers and material producers to integrate the appropriate activities, aids, drills... etc. that matches the preferred styles and strategies utilized by EFL students.

This study is a new addition to the educational research, which focuses on the role of learning styles on foreign language achievement. Furthermore, to the best of the researcher's knowledge, no study up to now has been conducted in Jordan that investigated the relationship between the perceptual learning styles on the achievement of EFL at the tertiary level.

\subsection{Questions of the Study}

The current study addresses the following questions:

1) What are the learning style preferences of English language students studying in Pioneer Educational School?

2) Is there any statistically significant correlation between students' academic achievements and their learning styles? 


\section{Theoretical Framework and Empirical Studies}

Learning style analysis has become a major concern in most sectors of education over the past fifteen years (Corbett \& Smith, 2012). For example, the Dunn and Dunn learning styles model (1995) focused on five domains (environmental, emotional, sociological, physiological and physiological) and twenty- one elements across those domains. The purpose of learning styles theory is to identify students' styles of learning and then provide materials and methods, which foster efficient and lasting achievement within a reasonable amount of time.

Regarding learning styles in foreign language learning (Bailey et al., 2000) believe that research into the role of learning styles in foreign language achievement could serve to help a significant number of students improved their foreign language or second language study habits, their learning flexibility and ultimately their performance.

Learning styles are concerned with how students prefer to learn not what they learn. No one style is better than others. The different styles may complement one another instead of competing with one another (Reid, 1998). The important thing that is helpful to students is to allow them to become aware of their own learning style preferences, yet encouraging them to develop less preferred styles which may suit different learning activities.

(Walsh, 2011; ZaiolAbdi, Razaee, Abullah, \& Singh, 2011; Pritchard, 2009, p. 123) have been identified the major characteristics' of visual, auditory, and kinesthetic learners as follows:

\section{Visual learners}

They learn best through seeing and prefer information to be presented visually in the form of pictures, posters, maps, diagrams, film, etc. Lectures do not work well for them, use lists to organize their thoughts and observe teacher's body language and facial expressions to fully understand. They love colors and show interest in the world around them.

\section{Auditory learners}

They prefer to collect information via listening. Some of these students learn best when the teacher explains things orally. The classroom activities they like to participate in are discussions, debates, role play and problem- solving, discuss ideas verbally with others and recite information over and over to better realize the learning materials. They benefit from formal lectures, repetition, questions, and presentations. Thus, auditory learners are talkative, conceptual, perceptual, and reflective and memory oriented.

\section{Kinesthetic learners}

They are movers of the educational world. They learn best when actively engaged in doing or touching something. They need to walk around or stand up while working. They enjoy physical activities, field trips, manipulating objects and hands- on experiences. They like to think out issues, ideas and problems while they exercise.

Visual and auditory styles were found to be the most preferred in some studies. (Lisle, 2005) conducted a study on students who have been diagnosed as having learning difficulties in courses such as poetry, arts and crafts in the UK. The findings showed that $34 \%$ have the visual preference, $34 \%$ have auditory, $23 \%$ have kinesthetic and $9 \%$ have multi-modal learning preferences. Therefore, it is suggested that the usual outcome from the visual, auditory and kinesthetic modality indicator (VAK) is $25-30 \%$ visual, $25-30 \%$ auditory, $15 \%$ group learning/ kinesthetic and $25-30 \%$ mixed modalities (Lisle, 2005). The above studies indicate a clear preference for visual style for college students in the U.S, New Zealand, Austria, and the UK.

In a study conducted by (Tavares \& Gloria, 2007) on eight teachers of English as a foreign language in the U.S, it was found that kinesthetic and extroverts are among the most learning styles favored. Data was collected through classroom recordings, questionnaire, and a guided interview. This indicates that second language teachers also have learning style preferences, however, in this study; teachers should use a variety of teaching activities and not focus on the activities that only reflect on kinesthetic style. Using a variety of teaching activities will match every student's learning style in the class.

Cultural issues can also influence perceptual learning style preferences. For example, (Stebbins, 1995) carried a longitudinal study on postsecondary ESL students in the U.S. The sample consisted of 764 Arab, Japanese, Chinese, Korean and Spanish students. The findings revealed that students showed strong preferences for the auditory mode, Spanish students showed strong preferences for the group leaning mode, and Korean students' strongly preferred visual style. Yet, Japanese and Chinese students expressed no strong preferences for any modality. 
Some studies also have revealed a significant positive relationship between learning styles and achievement in the English language proficiency as well as in other fields such as economics, mathematics, and sciences, other studies have not found such a significant positive relationship. It also presents research findings on style preferences of the participants from different proficiency levels. Some investigations on the effect of learning styles on achievement when it was matched to teaching styles have been presented.

Investigating the correlation between learning styles and achievement of high school students was the aim of a study conducted by Jekompoi (2007), on 100 high school students.

The sample consisted of 34 gifted students (those students who show potential for performing at high levels of accomplishment when compared to others of their age), 32 were not gifted but were college-bound, and the other 24 were neither gifted nor college-bound. Students' reliance on four learning styles was assessed. The findings indicated that gifted students relatively used each of the learning styles more than the other two categories of students. This finding indicates that learning styles have an effect on achievement.

Studies aimed at investigating how teaching learners the ways they prefer, results in better academic achievement have also been published. For example, a large- scale research has been conducted at more than 60 institutions of higher education in the United States and other countries. The researcher used Dunn and Dunn's learning styles model (this model consists of five stimuli which include environmental, emotional, sociological, physiological, and psychological elements). Students were taught with some methods, resources, or approaches that were complementary to their learning styles and others that are dissent from their learning-styles strengths. Students achieved statistically higher grades when they were taught in a way that was complementary to their learning styles (Dunn, originally cited in Neely \& Alm, 1992, p. 2).

Investigating style preferences of learners from different levels of proficiency was the aim of (Rossi Le's, 2000) study. Findings show a preference for visual learning by students with higher language proficiency. It has also been stated that more proficient ESL learners have probably had more exposure to the written word, and therefore feel comfortable learning visually.

High achievers also show a preference for visual and kinesthetic styles in the study carried out by (Cutolo \& Rochford, 2007). The researchers designed a study on 2,597 incoming freshmen in a private university located in a large metropolitan area. The study was conducted economics students and instructors at Saint Mary's College of California. It aimed at identifying the relationship between learning style preferences and academic achievement. The results revealed that specific learning style preferences correlate with achievement and that learning style preferences are varied according to academic performance.

(Park, 2001) investigated the relationship between learning styles and achievement between different ethnic groups. The study concerned the basic perceptual learning style preferences for the group and individual learning of Armenian, African, Hispanic, Hmong, and Korean, Mexican, and Anglo secondary school students. The result revealed significant students' achievement level differences.

(Li \& Qin, 2003) present an interesting contrast to the findings of the aforementioned studies. The sample consisted of 187-second year college non-English major students. The study aimed at investigating the relationship between learning styles of a group of Chinese EFL college students and their language learning outcomes. The version of the Myrers-Briggs Type Indicator Form G (MBTI- G) was used. The findings revealed that learning styles were only weakly or indirectly related to language learning outcomes. Similarly, (Diseth \& Martinsen, 2003) conducted a study to analyze the relationship between approaches to learning (deep, strategic, and surface), cognitive style, motives and academic achievement on 192 undergraduate students. The results similarly revealed that styles only had indirect effects on achievement.

\section{Methods}

In the present study is of a descriptive type, the data was collected, and analyzed the statistical package for social sciences.

\subsection{Population and Sample of the Study}

The population of the study included all the tenth- grade students in private schools / Amman. The study sample consisted of 166 students schools from Pioneer Educational School. The sample was selected purposely because of its relevance to the researcher regarding the procedure used.

\subsection{Instruments}

Questionnaires are quick and efficient in obtaining the necessary information. They enable participants to give precise answers without elaboration and enable the same amount of data to be obtained from all respondents and 
uniformly organized for statistical analysis. The Lickert scale was used in measuring the students' answers by ticking the box they feel appropriate and each answer had its own. Scoring is illustrated in table one.

Table 1. Scores of the student's questionnaire answers

\begin{tabular}{llllll}
\hline Answers & Strongly Agree & Agree on & Neutral & Disagree & Strongly Disagree \\
\hline Scores & 5 & 4 & 3 & 2 & 1 \\
\hline
\end{tabular}

The modified version of the PLSP questionnaire is represented in tables $(2,3,4, \& 5)$

a) Visual style includes items: $(3,7,9,17,20)$.

Table 2. Visual style

\begin{tabular}{ll}
\hline Item & Statement \\
\hline 3 & I learn better by reading what the teacher writes on the chalkboard. \\
7 & When I read instructions, I remember them better. \\
9 & I understand better when I read instructions. \\
17 & I learn better by reading than by listening to someone. \\
20 & I learn more by reading textbooks than by listening to lectures. \\
\hline
\end{tabular}

b) Auditory style includes items: $(1,4,6,13,15)$.

Table 3. Auditory style

\begin{tabular}{ll}
\hline Item & Statement \\
\hline 1 & When the teacher tells me the instructions, I understand better. \\
4 & When someone tells me how to do something in class, I learn better. \\
6 & I remember things I have to hear in the class better than things I have read. \\
13 & I learn better in class when the teacher gives a lecture. \\
15 & I learn better in the class when I listen to someone. \\
\hline
\end{tabular}

c) Kinesthetic style includes items: $(2,5,11,14,19)$.

Table 4. Kinesthetic style

\begin{tabular}{ll}
\hline Item & Statement \\
\hline 2 & I prefer to learn by doing something in class. \\
5 & When I do things in class, I learn better. \\
11 & I enjoy learning in class by doing experiments. \\
14 & I understand things better in the class when I participate in role-playing. \\
19 & I learn best in class when I can participate in related activities. \\
\hline
\end{tabular}

\section{d) Group learning style includes $(8,10,12,16,18)$.}

Table 5. Group learning style

\begin{tabular}{ll}
\hline Items & Statement \\
\hline 8 & I prefer work with my classmates. \\
10 & I learn more when I study with groups. \\
12 & I study better when I study with others in the class. \\
16 & I enjoy assignment with my classmates. \\
18 & I prefer to study with my friends. \\
\hline
\end{tabular}




\subsection{Data Analysis}

The present study is of a descriptive type. The data was collected through the learning style preferences questionnaire and it was analyzed using statistical techniques.

\section{Findings and Discussions}

The purpose of this study is to investigate the learning styles used by Jordanian EFL students. The learning styles are visual, auditory, group learning and kinesthetic. The study also aims at finding out the correlation between the learning styles on the learner's achievement.

One instrument is used (Reid's, 1998) learning style preference questionnaire. Learners' achievement was measured by grade point average they achieved in the first- semester final examination (December 2017) which was designed by the ministry of education. The current study provides a detailed description of the Jordanian learners learning styles preferences. Thus, it can be stated that the current study is unique in that:

1) It investigates specifically the perceptual learning styles at schools and their relationship with achievement.

2) The findings of the study may add something new to the scientific research.

Question one: What are the learning style preferences of English language students studying in Pioneer Educational School?

To answer the first question, descriptive analysis was performed and the means of all styles (auditory, group learning, kinesthetic and visual) were calculated. The mean and standard deviation for each learning style are shown in table six

Table 6. Means of the learning style preferences

\begin{tabular}{lll}
\hline Styles & Mean & SD \\
\hline Auditory & 20.66 & 2.18 \\
Group learning & 20.30 & 2.50 \\
Kinesthetic & 18.91 & 2.35 \\
Visual & 18.42 & 2.21 \\
\hline
\end{tabular}

Table six shows that the Jordanian students rely heavily on a traditional approach to teaching, which is lecturing which was based on audio/lingual method of teaching when they were studying at schools which developed auditory (hearing) styles to make notes and memorize information. In this study, visual style was found to be the least preferred.

It is clearly in table six that Jordanian EFL learners in schools used all types of learning styles included in the questionnaire, but in different degrees. The following tables $(7,8,9$ and 10) show the individual items in each for the four learning styles with the means and standard deviations.

Table 7. Means of individual items for auditory style

\begin{tabular}{llll}
\hline Item & Statements & M & SD \\
\hline 4 & When someone tells me how to do something in class, I learn it better. & 4.46 & 0.75 \\
6 & I remember things I have heard in class better than things I have read. & 4.35 & 0.79 \\
1 & When the teacher tells me the instructions, I understand better. & 4.07 & 0.93 \\
15 & I learn better in class when I listen to someone. & 4.43 & 0.06 \\
13 & I learn better in class when the teacher gives a lecture. & 3.36 & 1.12 \\
\hline
\end{tabular}

It is clear that auditory style heads the list of the learning styles. Learners seem to be influenced by the approach they used to when they were at schools i.e., lecturing. Those learners were the outcomes of the old syllabus, which was based on the audio-lingual method since the teacher was the center of the learning process and the learners' role was to receive knowledge. As noticed, all statements focus on hearing knowledge presented and the learners' role was to receive and memorize it. 
Table 8. Means of individual items for group learning style

\begin{tabular}{llll}
\hline Items & Statements & M & SD \\
\hline 10 & I prefer work with my classmates. & 4.53 & .84 \\
18 & I learn more when I study with groups. & 4.40 & .79 \\
8 & I study better when I study with others in the class. & 4.27 & .94 \\
16 & I enjoy assignment with my classmates. & 3.66 & 1.07 \\
12 & I prefer to study with my friends. & 3.45 & 1.17 \\
\hline
\end{tabular}

The group learning style is rated the second among the four learning styles. It is clearly noticed that learners learn more when they can. They learn easier, faster, transferable to new situations and more co-operative with his friend in class. Furthermore, the student will be more self-directed, effective and more enjoyable.

Table 9. Means individual items of kinesthetic styles

\begin{tabular}{llll}
\hline Items & Statements & M & SD \\
\hline 2 & I prefer to learn by doing something in class. & 4.10 & .91 \\
14 & I understand things better in class when I participate in role-playing. & 4.01 & 1.04 \\
11 & I enjoy learning in class by doing experiments. & 3.85 & .96 \\
5 & When I do things in class, I learn better. & 3.51 & 1.19 \\
19 & I learn best in the class when I can participate in related activities. & 3.44 & 1.06 \\
\hline
\end{tabular}

Kinesthetic style preference ranked the third among learning styles it is surprising that kinesthetic style was discovered to be the third preference although learners in this school should use their whole body movement (kinesthetic) while learning. This finding can be explained by the fact that not all school curricular train learners to co experiments or make drawings or projects while learning.

Table 10. Means individual items for visual styles

\begin{tabular}{llll}
\hline Items & Statements & M & SD \\
\hline 17 & I learn better by reading than by listening to someone. & 4.26 & .75 \\
9 & I understand better when I read instructions. & 4.04 & 1.06 \\
7 & When I read instructions, I remember them better. & 3.58 & 1.04 \\
3 & I learn better by reading what the teacher writes on the chalkboard. & 3.52 & 1.18 \\
20 & I learn more by reading textbooks than by listening to lectures. & 3.02 & 1.20 \\
\hline
\end{tabular}

The visual style was found to be the least preferred style in the current study. Thus, the finding that the visual style was the least preferred maybe due to the fact that Jordanian is an agent country.

In brief, the findings revealed that Jordanian learners referred all the learning styles but at different degrees or preferences.

Question Two: Is there any statistical correlation between achievement and their perceptual learning style?

A correlation test (Pearson) was performed to determine if a difference existed between high achievers and under-achievers in the use of perceptual learning styles.

Table 11. Summarizes the mean scores of the four styles

\begin{tabular}{lllllll}
\hline \multirow{2}{*}{ Auditory } & Achievement & $\mathrm{N}$ & Mean & SD & T & SIG \\
& High & 91 & 20.60 & 2.34 & -0378 & 0.706 \\
Kinesthetic & Low & 75 & 20.73 & 1.99 & & \\
& High & 91 & 18.70 & 2.58 & -1.281 & 0.202 \\
Visual & Low & 75 & 19.17 & 2.04 & & \\
& High & 91 & 18.52 & 2.25 & 0.638 & 0.525 \\
Group learning & Low & 75 & 18.30 & 2.19 & & \\
& High & 91 & 20.15 & 2.44 & -0.867 & 0.387 \\
& Low & 75 & 20.49 & 2.60 & & \\
& High & 91 & 77.98 & 6.61 & -0.738 & 0.462 \\
& Low & 75 & 78.70 & 5.80 & & \\
\hline
\end{tabular}

Note. The mean difference is significant at the 0.05 levels. 
The statistical analysis of the findings in table 10 suggests that at least for this sample of Jordanian learners in Pioneer Educational School, learning styles do not correlate to foreign language achievement. This can be explained that teachers, parents, and administrators often fail to consider the different styles when assessing students although. Learners depend on the same learning styles, normally the auditory style, the learners misunderstanding of their individual styles and their unawareness of their modalities strength.

A summary of the results is as following: 1) It is clearly noticed that the auditory style is the most preferred by Jordanian EFL learners in Pioneer Educational School; 2) Statistical analysis showed no significant correlation between learning styles and achievement.

\section{Conclusion}

The current study identified the learning styles of school students. Furthermore, it identified the preferred learning styles on the student academic achievement. The Jordanian students in this study were found to prefer auditory style to the other free learning styles.

The following are the recommendations for further research, It is recommended that similar studies should be conducted by applying different instruments besides the questionnaire such as inventories, interviews, observations; researchers will gain adequate data about learning styles and achievement in the foreign language. More research is needed concerning the correlation between learning styles and achievement. Further research should continue to investigate whether any of learning styles variables interact with learning strategies and results in a better achievement in the foreign language classes.

\section{References}

Bailey, P., Onwuegbuzie, A. J., \& Daley, C. E. (2000). Using learning styles to predict foreign language achievement at the college level. System, 28. https://doi.org/10.1016/s0346-251x(99)00064-0

Bostrom, L., \& Lassen, L. M. (2006). Unraveling learning, learning styles, learning strategies and meta-cognition. Education + training, 84. https://doi.org/10.1108/00400910610651809

Corbett, S. S., \& Smith, F. W. M. (1984). Identifying students learning styles: Proceed with caution. The Modern Language Journal, 68. https://doi.org/10.1111/j.1540-4781.1984.tb01566.x

Cutolo, A., \& Rochfor, R. A. (2007). An analysis of freshman learning styles and their relationship to academic achievement. College Quarterly, 10(2). Retrieved from http://www.senecac.on.ca/quarterly/2007-vol-10

Diseth, A., \& Martinsen, O. (2003). Approaches to learning, cognitive style, and motives as predictors of academic achievement. Educational Psychology, 23(2). https://doi.org/10.1080/01443410303225

Dunn, R. S., \& Dunn, K. J. (1995). Learning styles/ teaching styles: Should they..canthey..be matched? Educational Leadership, 36, 238-244.

Dunn, R., \& Griggs, S. (1995). Multiculturalism and Learning Style: Teaching and Counseling Adolescent. Westport, CT: Greenwood Publishing.

Dunn, R., \& Griggs, S. A. (1988). Learning styles: Quiet revolution in American secondary schools. Reston, Virginia: National Association of secondary school principals.

English Language Curriculum Department. (1999). English language curriculum framework. Oman: The ministry of Education.

Heather, T., Cox, R., \& Takahiro, K. (2000). Relating preferred learning style to student achievement. N/A. Retrieved from http://eric.ed.giv/ERICWebPortal/Home.prtal

http://www.informaworld.com.ezproxy.library.uq

Jepkemboi, G. (2007). A comparison of learning styles between gifted and non-gifted high school students. Childhood Education, 83. Retrieved from http://proquest.umi.com.ezaproxy.library.uq.edu.au/

Li, J., \& Qin, X. (2003). The relation of learning styles to language learning outcomes: An empirical study. Hong Kong Journal of Applied Linguistics, 8(1). Retrieved from http://proquest.umi.com.ezproxy.library.uq.edu

Lisle, A. M. (2005). The development of an inventory to assess the learning styles of adults with learning difficulties. Journal of Intellectual Disabilities, 11. Retrieved from http://www.eric.ed.gov/ERICWebPortal/Home.portal

Neely, R. O., \& Alm, D. (1992). Meeting individuals needs: A learning style success story. Clearing House, 66(2). https://doi.org/10.1080/00098655.1992.9955945 
Park, C. C. (2000). Learning style preferences of southeast Asian students. Urban Education, 35(3). https://doi.org/10.1177/0042085900353002

Park, C. C. (2001). Learning style preferences of Armenian, African, Hispanic, Hmong, Korean, Mexican, and Anglo students in American secondary schools. Learning Environment Research, 4(2). https://doi.org/10.1023/A:1012463316737

Pritchard, A. (2009). Ways of Learning: Learning Theories and Learning styles in the Classroom (2nd ed.). London: Routledge.

Reid, M. J. (1998). The learning style preferences of ESL students. TESOL Quarterly, 21(1). Retrieved from http://www.jstor.org.ezproxy.slv.vic.gov.au/

Rossi-Le, L. (2000). Learning styles and strategies in adult immigrant ESL students. In M. J. Reid (Ed.), Learning styles in the ESL/EFL classroom (pp. 118-125). Boston, Massachusetts: Heinle \& Heinle Publishers.

Stebbins, C. (1995). Cultural- specific perceptual- learning- styles preferences of postsecondary students of English as a second language. In M. J. Reid (Ed.), Learning styles in the ESL/EFL classroom (pp. 108-117). Boston, Massachusetts: Heinle \& Heinle Publishers.

Tavares, G., \& Gloria, M. D. (2007). A matter of style: Looking at L2 teachers' teaching styles from the perspective of learning style. Linguagem \& Ensino, 10(1). Retrieved from http://www.eric.ed.gov./ERICWebPortal/Home.portal

Walsh, B. (n. d.). Visual, Auditory, and Kinesthetic Communication and learning Styles. Wash Seminars Publishing House.

ZaiolAbdi, M., Razaee, A., Abdullah, H., \& Singh, K. (2011). Learning Styles and Overall Academic Achievement in a Specific Educational System. International Journal of Humanities and Social Science, l(10), 143-152.

\section{Copyrights}

Copyright for this article is retained by the author(s), with first publication rights granted to the journal.

This is an open-access article distributed under the terms and conditions of the Creative Commons Attribution license (http://creativecommons.org/licenses/by/4.0/). 